\title{
Humanitarian welfare values in a changing social environment: A survey of social work undergraduate students in Beijing and Shanghai
}

Journal of Social Work 0 (0) $1-19$

(C) The Author(s) 2010 Reprints and permissions: sagepub.co.uk/journalsPermissions.nav DOI: I0.1 I77//468017310380294 jsw.sagepub.com

(\$SAGE

\section{Vivian WQ Lou}

The University of Hong Kong

\section{Veronica Pearson}

The University of Hong Kong

\section{Yu Cheung Wong}

The University of Hong Kong

\begin{abstract}
- Summary: Internationally accepted social work values are based on ideas about rights, social justice and equitable resource distribution. Does social work education in China embody similar values? Are these values influenced by culture and the current political/ economic environment? The research posed three questions. Do social work students studying in metropolitan China support humanitarian welfare values? Are values affected by demographic backgrounds? Does social work education enhance humanitarian values? A self-administered, standardized questionnaire was distributed in 26 classes of social work students studying in seven universities in Beijing and Shanghai $(n=1328)$. - Findings: Students do not support humanitarian welfare values strongly; and a decrease in these values was observed in senior students. Significant differences in values were found based on gender and on rural/urban origins. Female students were more likely to agree with humanitarian value statements; rural and urban students tended to agree more with values from which they had potential to benefit.

- Applications: Social work knowledge and skills rather than values maybe more immediately relevant to Chinese society. However, independent professional practitioners need a solid foundation of professional values to inform practice and standardize the
\end{abstract}

Corresponding author:

Vivian WQ Lou, Department of Social Work and Social Administration, Sau Po Centre on Ageing, The University of Hong Kong, Pokfulam Road, Hong Kong

Email: wlou@hku.hk 
social work role. There needs to be an ongoing debate in China involving social work educators and practitioners about values and their relation to Chinese society, the ways in which they are influenced by non-Chinese cultures; and how to infuse these consistently into social work curricula in Chinese universities.

\section{Keywords}

Chinese, humanitarian welfare attitudes, social work education, social work students, urban and rural comparison

\section{Introduction}

The teaching of all social science subjects was forbidden in China in the late 1950s and it was not until the end of the 1980s that the first undergraduate social work program was established. Since then programs have proliferated and around 200 are now offered throughout China (CASWE, 2009). The Chinese Association of Social Work Education (CASWE) has laid down guidelines for curriculum development and a survey of programs has shown that the curriculum coverage of core courses is comparable to international recommendations (Lou, Gu, Kuan, \& Leung, 2006).

However, social work is a value based profession, in which not only knowledge and skills are stressed, but also the rationale for why vulnerable people are deserving of care and help. Professional education imbued with humanitarian welfare values focusing on commitment to both human rights and social justice is argued to be as important as the acquisition of knowledge and skills (IASSW and IFSW, 2009). Students who are less committed to humanitarian ${ }_{\Lambda}$ values are also less likely to seek social work jobs after graduation; or, if they do join the social work field, are less likely to demonstrate values believed to be core to the profession (Rompf \& Royse, 1994; Tam, 2003). On a macro-level, values have both implicit and explicit influences on welfare policy, planning and service and in turn are affected by shifts in ideology as governments come and go (Banks, 2001).

Recent studies in Shanghai and Beijing found that only about 30 percent of social work graduates occupied social work positions five years after graduation. Some of the barriers are systemic, such as lack of job opportunities and lack of opportunities for front-line workers to provide professional services (Wong, 2002; Xie, 2006; Yu \& Li, 2006). However, another study of career choice values held by college students found that students placed less stress on professional loyalty and more on economic returns, such as salary, job welfare and individuals' self-interest (Jia \& Zheng, 2006). As far as we are aware, the only empirical work conducted in China that aimed to study the commitment to the professional values of social work students is that by Tam $(2001,2003)$.

Values, including humanitarian welfare values, are embedded in a social system that responds to social and economic changes. From an ecological point of view, college students' value commitment is both environmentally sensitive and life 
history dependent (Bronfenbrenner \& Morris, 1998). Humanitarian $\lambda_{\wedge}$ alues are central to social work education, professional development, and social policy and service planning. Consequently, when studying the trajectory of the development of social work in China, it is crucial to examine the degree to which social work students in China share international professional perspectives on humanitarian values. Chinese students have grown up within a context that has experienced rapid changes in welfare ideology, policy and implementation, coterminous with China's economic development over the last 40 years. Hence, education about humanitarian welfare values is embedded in three contextual forces: traditional values and their current normative forms, the social welfare regime and its recent reforms, and students' teaching and learning experiences. To complicate an already complex situation, there is no guarantee that these three forces will agree with or complement each other. Mindful of the changing social context, the present study set out to answer the following research questions:

1. Do social work students studying in metropolitan China support humanitarian welfare values?

2. Do students with different demographic backgrounds differ in their attitudes towards humanitarian welfare values?

3. Does social work education in metropolitan China enhance students' humanitarian welfare values?

\section{Humanitarian welfare values}

A value may be defined as 'one or all of moral, religious, political or ideological principles, beliefs or attitudes'. Put in the social work context, social work values refer to 'a set of fundamental moral or ethical principles to which social workers are/should be committed' (Banks, 2001: 6).

Humanitarian welfare values were one of the normative foundations for the early development of social work. Since then such values have become one of the three pillars (values, knowledge, skills) of the social work profession, influencing welfare policy, guiding professional education and practical ethics (Kendall, 2000; Pullen, 2006). These values were built on two sources. One is rooted in Kantian moral philosophy - the principle of respect for persons. This has been used to underpin the social worker-service user relationship. The second derives from utilitarian philosophy which focused on utility and justice and underlies the social work principles of social justice and equality (Banks, 2004). The emergence of critical social science and neo-liberalism political-economic philosophy in the 1980s challenged the foci and implementation of the two key value components in practice, but the value statements remained unaltered and continue to play a leading role in value principles (Pullen, 2006). Although there has been no consensus on the precise content of these two guiding principles, the international professional social work community is in agreement that it is essential to educate social work 
students about both social justice and human rights as part of inculcating human-

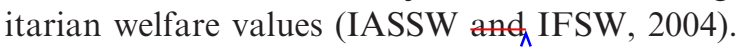

Welfare ideology is a culturally sensitive phenomenon, in which different countries have their own tradition and history (Chow, 1987; Huang, 2006). Humanitarian values such as respecting human rights and human needs, citizens' rights and social justice are deeply rooted in the Christian ethos of charity and brotherly love that should encompass all, family, friend and foe alike. Such an approach is different from Chinese views about charitable giving that emphasize material relief for those who have failed to obtain support through family and kin. Chinese people hesitate to seek assistance from the government, but are prepared to ask for family support. Although social work degree and associate degree programs in China have mostly adopted a similar curriculum design as that followed in Western countries, social work professionalization is in its infancy and humanitarian values have not been officially adopted (Lou et al., 2006; Ministry of Civil Affairs, 2009). In summary, Chinese cultural traditions and the current development of social work education do not appear to share normative expectations about the principle of respect, social justice and equality on a universal basis.

\section{The ecology of humanitarian welfare value $e_{\lambda}$ education
modern China}

As mentioned before, there are at least three contextual forces embedded in the changing social environment of today's China that assist us to understand the ecology of humanitarian welfare values in the education of social work students.

\section{Traditional values and their current normative forms}

Values, as a socializing product, are influenced by multiple factors, particularly society, family, and peers (Bronfenbrenner \& Morris, 1998; Yan, 2006). With more than 5000 years of history, Chinese cultural tradition has absorbed influences from Confucianism, Buddhism, Taoism, capitalism, and socialism. Without the necessarily being a consensus on key features of Chinese cultural traditions, there is wide agreement on several key factors that have had a profound influence on human development and behavior in China, such as emphasizing obligations rather than rights, family rather than individuals, hierarchy rather than equality (Bond, 1988; Yang, 2004). Welfare was regarded as a product of the benevolence of the emperor and other wealthy people willing to help the poor, and was a public demonstration of virtue (Chow, 1987). The socialist revolution in 1949 and the economic and social reforms in China that have since taken place, particularly from 1980 onwards, have generated a mixed value structure with socialist/Confucian, capitalist, and feudalist influences (Cheung \& Kwok, 1999; Lu, 2008). Hence, humanitarian values are not dominant in Chinese culture and their introduction may create tension between them and normative expectations in the Chinese context (Huang, 2006). 
Recent studies among Chinese young people have found that they have developed a set of mixed values as a result of the economic and social reforms ( $\mathrm{Lu}, 2008$; Yan, 2006). On one hand, they inherited collectivist-oriented values such as a sense of family obligation, being involved in the community, and doing volunteer work to help the less fortunate. On the other hand, individualistic values such as human rights, legal protections, and autonomy have been emerging. This has taken place in a context where individual effort has been increasingly emphasized in relation to personal as well as family welfare, alongside the influences of Western cultures in the modernization process. Young people have inherited tradition but welcomed the possibilities offered by individual autonomy and the pursuit of new goals. They are more flexible when compared with the older generation, as reflected in their career choices (Jia \& Zheng, 2006) and better able to accommodate change. Social work students share some of these features with their peers.

\section{The social welfare regime and its reform}

The current cohort of social work students has experienced some of the most fundamental socio-economic and welfare changes to have happened since 1949. The cradle-to-the-grave welfare system established in the urban areas after the Chinese Communist Party came to power in 1949 has been superseded by one based on a mixed economy of welfare from the 1990s onwards (Croll, 1999). This involved the sharing of welfare provision between the central government, local government, work unit, and individuals and their families (Lu \& Feng, 2008). Individuals were expected to carry much greater responsibility for the provision of 'welfare goods' previously provided free by the state - housing, employment, education, and health care. Legal systems have been developed and strengthened which aim to protect the rights of citizens ( $\mathrm{Liu}, \mathrm{Li}$; \& Feng, 2008; Lubman, 1999). The public perception of this shift to a political economy underpinned by a pro-neoliberal philosophy was by no means positive (Jiang, 2008). It not only changed the basis of welfare provision but also the underpinning welfare ideology - individuals are expected to take more responsibility for their own welfare, while the government has shifted to a policy of very selective welfare provision. As a consequence, gross inequalities in housing and health provision have been observed and become the target of discussion (Gustafsson, $\mathrm{Li}_{;} \&$ Sicular, 2008). The older generation, fed a life-long diet of socialist rhetoric and used to a world of fixed certainties, found it hard to accommodate the changes. But many younger people relished the new opportunities, responsibilities and personal freedoms that attended liberalization.

Social work students are of this new generation who may be considerably less willing to accept society's obligation to care for the weak and vulnerable, because the funding comes from their pockets in the form of taxes. Hence, exploring humanitarian ${ }_{\Lambda}$ values among social work students will not only contribute to the understanding of social work education in China, but also shed light on professional value building in a context where traditional values, professional values, and current welfare ideologies are in a state of flux. 
The economic reforms have precipitated vast changes in how much welfare is provided and who is expected to take responsibility for its provision (Banks, 2001). The family is still the most significant provider of care for the young, old, sick and enfeebled and receives precious little support from outside sources. Discussion about welfare ideologies is not common, perhaps a reflection of traditional values where there was little expectation of receiving help external to the family, and the gap between the rich and poor grows ever wider. Meanwhile, the national Gini coefficient (a measure of the disparity in income distribution) in 2005 was estimated to be 0.44 (including the migrant population in urban areas) which was more than 1.5 times the figure for 1982 (Chen, Hou; \& Jin, 2008; United Nations Human Development Report Office, 2005). Welfare provision is moving towards being a reward for effort and ability (higher salary associated with higher contributions and higher benefits) rather than an individual right.

These changes create a dilemma for social work students. A career has been created post-graduation, but the career path is far from clear, the pay is comparatively low and does not provide attractive welfare benefits. In such circumstances joining the social work profession becomes a value driven decision in which, presumably, compassion is given more weight than money, security or power (Liu, 2006). This question of underlying motivation is closely related to the purposes of this study.

\section{Teaching and learning experiences of the students}

As discussed previously, social work is a profession that stresses equipping students with knowledge and skills for the enhancement of the well-being of individuals, families, groups and communities. Such specialist knowledge and skills rest on a normative foundation of values regarding the reasons why communities are responsible for providing assistance to their vulnerable members (Banks, 2004; IASSW and $\mathrm{I}_{\lambda} \mathrm{FSW}$, 2004). In countries where social work has been long-established the inculcation of humanitarian values is expected to be achieved through multiple channels such as the acquisition of knowledge, skills training, reflection, interaction with qualified social workers, and the teaching provided by their social work teachers (Moran, 1989). As a result of being exposed to social work professional education, students' values and beliefs are said to become more liberal, humanitarian and socially responsible (Lottes \& Kuriloff, 1994; Pascarella \& Terenzini, 1991). The longer the duration of study, the greater the influence is thought to be.

However, in China this modeling effect by professional practitioners and social work teachers is in some doubt. When social work courses first began to be taught in the late 1980s neither professionally trained social workers nor trained social work educators existed. Even now the majority of those teaching social work are not trained in the social work field (Lou et al., 2006). Not surprisingly, social work graduates reported that they lacked competence in the skills of social work practice (Wong, 2002; Xie, 2006). An authoritarian teacher-student relationship is still the norm in China, even in tertiary institutes (Chan \& Chan, 2005). It is doubtful how 
much teachers emphasize modeling humanitarian values through their teaching or engaging in extra curricula activities. In addition, research and academic discussion on the normative foundations of social work in Chinese societies is not very common (Gray, 2008; He \& Wang, 2000). Nor has the social work profession been recognized or promoted by the Chinese government until recently. Humanitarian values were not officially recognized in the official National Occupational Standards for Social Workers. The only value mentioned was 'helping people to help themselves' (Ministry of Civil Affairs, 2009). Finally, students who study social work do not necessarily choose to do so. Routinely, less able applicants to more popular subjects are offered places to study a less popular subject, including social work (http://www.213bbs.com/bbs/thread-3752-1-1.html).

All in all, the context in which the teaching and practice of social work exists in China is not fully conducive to its development. Cultural, economic and political values are changing rapidly inside China and impinge greatly on the development of a profession which is ultimately a non-Chinese invention planted in foreign soil. During the process of professional social work development in China, experiences from overseas countries, Hong Kong in particular, have been absorbed. However, the Chinese government and scholars place very great emphasis on the need to develop social work with Chinese characteristics (Hutchings \& Taylor, 2007; Jia, 2007). It is a theme that dominates discourse. In short, the National Occupational Standards for Social Work do not recognize humanitarian values officially. Teachers of social work are largely professionally unqualified and do not exemplify the humanitarian values that are thought to be the core of social work. Nor are these values considered by all to be legitimate in a climate that favors neo-liberalism rather than socialist communitarianism. Many social work students are not highly motivated because they did not choose to study the subject. Social work graduates also have difficulty finding social work related jobs.

Precisely because of these issues, this study set out to examine whether social work students were able to develop and maintain humanitarian oriented values and to test the enlightening effect of university education, particularly in relation to social work. Cheung and Kwok (1998) studied a group of social science students in China and found that not only was there no enlightening effect but that students' values became more conservative as their studies continued. This would be of serious concern if it were also to be found to be the case for social work students. Further researches found that individuals' background characteristics and volunteering experiences appeared to be correlated with college students' values and social work competence. Males and students from wealthier family backgrounds seemed more likely to believe that individuals should take more responsibility for their welfare (Cheung \& Kwok, 1999). Students' volunteering experiences were associated with social work competence (Cheung \& Tang, 2010).

In sum, the above discussion suggests that current social work students are facing tensions between the interactions of three forces: 1) Chinese traditional values are less coherent with humanitarian oriented welfare values as compared with Western traditions. This could influence students' socialization via the family 
and schools; 2) the current welfare changes in China are guided by a neoliberal welfare ideology but discussion of this topic is subject to political constraints. However, personal experiences as well as the experiences of close family members could have impacted on students' value formation and orientation; and 3) the teaching and learning experiences in social work programs will reflect the influence of teachers, peers, and placement experiences. The modernization process and the changing welfare regime within China, and the access of current university students to a wide range of material via electronic media are potential positive forces towards developing humanitarian values (see Table 1). It may well be, however, that the negative forces contained in the three contextual factors are stronger and will effectively resist the nurturing of humanitarian values among social work students in China.

\section{Methodology}

A self-administrated, standardized questionnaire was used for the survey distributed to 26 classes of social work students studying in seven universities in Beijing and Shanghai.

\section{Sample}

The study sample was recruited from seven universities offering social work programs in Beijing and Shanghai. The cities of Beijing and Shanghai were selected because they were the first to develop social work programs, and their universities have played a leading role in social work training in China. It is virtually impossible to collect a representative sample officially unless the study is carried out by or

Table I. Three key factors affecting the development of humanitarian welfare values

\begin{tabular}{|c|c|c|}
\hline & Positive forces & Negative forces \\
\hline $\begin{array}{l}\text { Cultural tradition } \\
\text { (via family) }\end{array}$ & $\begin{array}{l}\text { Cultural influences during the } \\
\text { process of modernization } \\
\text { and globalization }\end{array}$ & $\begin{array}{l}\text { Welfare is a form of charity } \\
\text { Family based } \\
\text { Accepting welfare indicates } \\
\text { personal/family failure }\end{array}$ \\
\hline $\begin{array}{l}\text { Current welfare } \\
\text { arrangements }\end{array}$ & $\begin{array}{l}\text { Legal system establishment } \\
\text { Government responsibility } \\
\text { for the most needy }\end{array}$ & $\begin{array}{l}\text { Personal responsibility } \\
\text { Status (urban vs rural) related } \\
\text { Employment (competence, education) } \\
\quad \text { related } \\
\text { Shared responsibility }\end{array}$ \\
\hline College education & $\begin{array}{l}\text { Social work training } \\
\text { Multicultural exposure } \\
\text { during the university life }\end{array}$ & $\begin{array}{l}\text { Faculty members may lack commitment } \\
\text { Inappropriate teaching style } \\
\text { Peer influences } \\
\text { Self-interest in career development }\end{array}$ \\
\hline
\end{tabular}


under the auspices of the government, which in itself presents almost insuperable problems. Consequently, to ensure representativeness, the social work programs were purposefully selected to include undergraduate degree and sub-degree programs with students studying in part-time and full-time modes, from different levels of university. Seven universities/colleges were selected, within which two are run by the Ministry of Education, three by local government, one by the Ministry of Civil Affairs, and one by the All-China Women's Federation. Two of them were located in Beijing and five in Shanghai. All social work students studying in the seven institutions during the period November 2002 to March 2004 were invited to complete the questionnaire. Although this was not a random sample efforts were made to ensure that it was broad and inclusive and such sampling procedures have been used in other studies (Chen, Wong, Ran, \& Gilson, 2009).

The demographic characteristics of the sample are shown in Table 2. More than 70 percent of the respondents were female and came from urban areas in China. Their ages ranged from 16 to 29 with a median age of 20. Years 1, 2 and 3 each contributed about 30 percent of the sample while around 10 percent belonged to Year 4.

Table 2. Sample characteristics $(N=1328)$

\begin{tabular}{|c|c|c|}
\hline & Frequency & Percentage (\%) \\
\hline \multicolumn{3}{|l|}{ Gender } \\
\hline Male & 348 & 26.2 \\
\hline Female & 980 & 73.8 \\
\hline \multicolumn{3}{|l|}{ Program } \\
\hline Degree & 856 & 64.5 \\
\hline Sub-degree & 472 & 35.5 \\
\hline \multicolumn{3}{|l|}{ Year of study } \\
\hline First year & 365 & 27.5 \\
\hline Second year & 394 & 29.7 \\
\hline Third year & 445 & 33.5 \\
\hline Fourth year & 124 & 9.3 \\
\hline \multicolumn{3}{|l|}{$A g e^{a}$} \\
\hline $16-19$ & 417 & 31.5 \\
\hline 20 & 410 & 31.0 \\
\hline 21 and above & 496 & 37.5 \\
\hline \multicolumn{3}{|c|}{ Place of living before university ${ }^{b}$} \\
\hline Urban & 922 & 70.4 \\
\hline Rural & 388 & 29.6 \\
\hline
\end{tabular}

Note: ${ }^{\mathrm{a}}$ Missing $=5$, ${ }^{\mathrm{b}}$ Missing $=10 \mathrm{k}$ 


\section{Measures}

Humanitarian welfare values were measured by 11 items that covered the two key principles (respect for individual rights and social justice) common to social work practice. This instrument was developed by Tam $(2001,2003)$ and was found reliable and valid among college students in Mainland China (Tam, 2001). It aimed to assess the extent to which respondents identified with the humanitarian orientation towards ideological issues considered crucial for the social work profession. These included the adequate distribution of resources, responsibility for social action aimed at the attainment of social justice, and respect for human needs and rights (Banks, 2001, 2004). Respondents were asked to indicate their degree of agreement with each item on a four-point scale $(1=$ Strongly Disagree, $2=$ Disagree, $3=$ Agree, $4=$ Strongly Agree).

\section{Procedure}

After obtaining informed consent, questionnaires were distributed by class teachers at the end of a class and students were asked to complete them anonymously. Students could choose to return their forms in class or later to that particular teacher. The return rate for 25 out of 26 classes was between 95 and 97 percent. One class of students in the final year of the BSW program had their placement during the data collection period. Questionnaires could only be distributed through their placement supervisors. This class had only a 31 percent return rate. Out of the 1343 questionnaires completed, 15 of them had more than 15 missing entries and were discarded. The remaining 1328 were included in the analysis.

\section{Data analysis}

Descriptive analysis was initially conducted. Analyses of variance were computed to explore enlightening effects. The duration of study was coded into two groups juniors (Years 1 and 2) and seniors (Years 3 and 4) because students usually undertook their placement during the two senior years. Multiple analyses of variance were computed to explore possible associated socio-demographic variables such as gender, place of secondary school education and urban versus rural home residence.

\section{Results}

\section{Humanitarian welfare values}

The frequency distribution of respondents' responses to each question on the scale is shown in Table 3. The top three statements were strongly supported by 40 to 50 percent of the respondents. They were 'the welfare of every person should be protected by the law' $(50.0 \%)$, followed by 'it is more important to enhance a person's well-being than to worry about the cost' $(39.5 \%)$, and 'all persons rich and poor, 
Table 3. Frequency distribution of respondents' positive and negative humanitarian welfare values $(N=1328)$

\begin{tabular}{|c|c|c|}
\hline \multirow[b]{2}{*}{ Item } & \multicolumn{2}{|c|}{ Percentage } \\
\hline & $\begin{array}{l}\text { Strongly } \\
\text { agree }\end{array}$ & $\begin{array}{l}\text { Strongly } \\
\text { disagree }\end{array}$ \\
\hline - The welfare of every person should be protected by the law & 50.0 & 0.2 \\
\hline $\begin{array}{l}\text { - All persons rich and poor, powerful or powerless should } \\
\text { receive similar kinds of health and welfare services }\end{array}$ & 39.5 & 2.3 \\
\hline $\begin{array}{l}\text { - It seems unfair to invest thousands of dollars in programs for } \\
\text { people such as mental patients and people with a learning } \\
\text { disability, who contribute nothing to society }\end{array}$ & 38.3 & 3.5 \\
\hline $\begin{array}{l}\text { - People should not be treated equally, because some are natu- } \\
\text { rally better than others }\end{array}$ & 33.2 & 5.4 \\
\hline $\begin{array}{l}\text { - In difficult economic times, programs benefiting the poor } \\
\text { should not be expanded }{ }^{\mathrm{a}}\end{array}$ & 24.1 & 2.6 \\
\hline $\begin{array}{l}\text { - It is more important to enhance a person's well-being than to } \\
\text { worry about the cost }\end{array}$ & 19.4 & 1.1 \\
\hline - There will always be poverty, so we might well get used to it ${ }^{\mathrm{a}}$ & 18.2 & 4.0 \\
\hline - Everyone in society should have a fair share of the resources & 15.8 & 7.2 \\
\hline $\begin{array}{l}\text { - It is hard to be sympathetic toward persons who claim they do } \\
\text { not get enough to eat }{ }^{\mathrm{a}}\end{array}$ & 14.5 & 5.4 \\
\hline $\begin{array}{l}\text { - Criminals are victims of an evil environment, they need help } \\
\text { but not punishment }\end{array}$ & 9.1 & 8.1 \\
\hline $\begin{array}{l}\text { - Every person should have a good house to live in, even if the } \\
\text { government has to provide it }\end{array}$ & 8.0 & 4.9 \\
\hline
\end{tabular}

Notes: ${ }^{\text {a }}$ igures for negative items were presented based on reversed score.

powerful or powerless should receive similar kinds of health and welfare services' $(38.3 \%)$. The statements which were least supported (supported by less than ten percent of respondents) were "every person should have a good house to live in, even if the government has to provide it' $(8.0 \%)$, and 'criminals are victims of an evil environment, they need help but not punishment' $(9.1 \%)$.

\section{Socioeconomic variables and humanitarian values}

MANOVAs were computed to explore possible associations between socioeconomic variables and humanitarian values among the respondents. Gender and urban/rural differences were identified. Gender differences were found on five out of $41_{\Lambda}$ items, in which women were reported to have more favorable humanitarian welfare values. The items were universal health and welfare services $(F=8.35$, $p<.01)$, taking care of mental patients $(F=21.73, p<.001)$ and the poor $(F=9.65, p<.01)$, and individual equality $(F=16.39, p<.001)$. Male respondents 
had higher scores favoring universal housing benefits $(F=4.04, p<.05)$. Students from urban areas were more in favor of universal health and welfare services $(F=15.60, p<.001)$ and housing benefits $(F=12.92, p<.001)$ than those from rural areas. Students from rural areas were less willing to accept that poverty is inevitable and should be accepted $(F=12.50, p<.001)$.

\section{Differences between junior and senior students}

ANOVAs were computed to examine the influences of social work education on humanitarian ${ }_{\Lambda}$ values by measuring the difference between the scores of junior and senior students. As shown in Table 4, senior students were significantly more likely

Table 4. Mean differences between junior and senior students in relation to humanitarian values $(N=1328)$

\begin{tabular}{|c|c|c|c|}
\hline Item & $\begin{array}{l}\text { Junior grade } \\
\text { mean (SD) }\end{array}$ & $\begin{array}{l}\text { Senior grade } \\
\text { mean (SD) }\end{array}$ & $F$ \\
\hline $\begin{array}{l}\text { The welfare of every person should be protected } \\
\text { by the law }\end{array}$ & $3.48(0.56)$ & $3.44(0.59)$ & 2.13 \\
\hline $\begin{array}{l}\text { It is more important to enhance a person's } \\
\text { well-being than to worry about the cost }\end{array}$ & $3.07(0.6 \mathrm{I})$ & $3.05(0.55)$ & 0.37 \\
\hline $\begin{array}{l}\text { All people rich and poor, powerful or powerless } \\
\text { should receive similar kinds of health and wel- } \\
\text { fare services }\end{array}$ & $3.24(0.77)$ & $3.21(0.72)$ & $0.4 I$ \\
\hline $\begin{array}{l}\text { It seems unfair to invest thousands of dollars in } \\
\text { programs for people such as mental patients and } \\
\text { people with a learning disability, who contribute } \\
\text { nothing to society }\end{array}$ & $3.22(0.78)$ & $3.15(0.77)$ & 2.46 \\
\hline $\begin{array}{l}\text { In difficult economic times, programs benefiting the } \\
\text { poor should not be expanded }\end{array}$ & $3.09(0.69)$ & $2.97(0.70)$ & $10.33^{*} * *$ \\
\hline $\begin{array}{l}\text { People should not be treated equally, because some } \\
\text { are naturally better than others }{ }^{\text {a }}\end{array}$ & $3.07(0.87)$ & $2.99(0.84)$ & $3.74 *$ \\
\hline $\begin{array}{l}\text { It is hard to be sympathetic toward people who } \\
\text { claim they do not get enough to eat }{ }^{\mathrm{a}}\end{array}$ & $2.69(0.77)$ & $2.77(0.77)$ & 3.37 \\
\hline $\begin{array}{l}\text { There will always be poverty, so we might as well } \\
\text { get used to it }{ }^{\mathrm{a}}\end{array}$ & $2.82(0.80)$ & $2.68(0.77)$ & 10.48 *** \\
\hline $\begin{array}{l}\text { Everyone in society should have a fair share of the } \\
\text { resources }\end{array}$ & $2.63(0.83)$ & $2.75(0.8 \mathrm{I})$ & $7.26 * *$ \\
\hline $\begin{array}{l}\text { Criminals are victims of an evil environment, they } \\
\text { need help but not punishment }\end{array}$ & $2.50(0.77)$ & $2.56(0.77)$ & 2.17 \\
\hline $\begin{array}{l}\text { Every person should have a good house to live in, } \\
\text { even if the government has to provide it for him }\end{array}$ & $2.39(0.72)$ & $2.54(0.69)$ & $|4.7|$ *** \\
\hline
\end{tabular}

Notes: ${ }^{a}$ Figures for negative items were presented based on reversed score. $*_{p}<.05 ; * * p<.01 ; * * * p .001$. 
to agree with two items: 'everyone in society should have a fair share of the resources' and 'every person should have a good house to live in, even if the government has to provide it'. No statistical differences were found between junior and senior students on six out of $11_{\Lambda}$ items. Junior students were significantly more likely than the senior students to agree with three items; 'in difficult economic times, programs benefiting the poor should be expanded', 'all people should be treated equally', and 'poverty is inevitable and should be accepted'.

\section{Discussion}

The present study explored humanitarian eriented-welfare values held by social work undergraduate students in Beijing and Shanghai. Results indicated that respondents did not demonstrate a strong commitment to humanitarian $\wedge^{\text {values }}$ in general. Socio-demographic variables such as gender, and rural versus urban origins were found to be associated with some values. The influence of social work

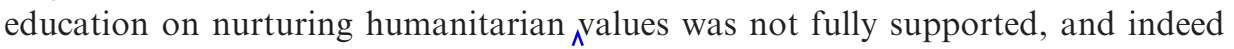
some values were more negative in senior than junior students.

Results showed that, on the whole, respondents did not demonstrate strong humanitarian values regarding welfare issues. Only half of the respondents strongly supported the item concerning legal protection; another three items on health services, services for vulnerable populations, and equality were supported by around thirty respondents. This was not surprising given the contextual factors discussed previously. When comparing our results with those obtained by Tam (2001) using the same scale, it was found that the most and least supported items were the same; the right to welfare protected by law, and well-being supported regardless of cost in the first case; and the fair sharing of resources, treatment rather than punishment for criminals, and universal housing provision in the second.

Agreeing that the welfare of every person should be protected by law is sufficiently imprecise as to not appear threatening to anyone fearful of giving up something of their own for the general good. It generates a strong 'feel good' factor without threatening consequences. Furthermore, participants may also have been influenced by publicity given to legal reforms emphasizing legal rights, promoted by various levels of the government as well as through the media in China (Liu et al., 2008; Lubman, 1999). Why was the notion of universal housing provision so unpopular among respondents? Housing is a highly valued and scarce resource in China while simultaneously being a basic human need. Before the economic reforms of the $1980 \mathrm{~s}$, housing $\Lambda^{\text {was }}$ owned and provided by the work unit based on performance and hierarchy and was free at the point of consumption (Chan \& Chow, 1992; Lu \& Feng, 2008). Since the mid-1990s housing reforms have created a privatized housing market and those with money may choose to improve their housing conditions through purchase. Private house prices have risen rapidly, especially in Shanghai and Beijing, and have become a major source of inequality (Gong \& Li, 2003; Gustafsson et al., 2008). Given the dominance of the pro-neoliberalism welfare ideology, it is not surprising to find that respondents 
tend not to support universal housing provision (Gong \& Li, 2003; Lee \& Zhu, 2006). Moreover, while undoubtedly the social work profession wishes to recruit the most committed students to its university programs, it is not necessarily able to do that. As we have already seen, it is a common practice that university applicants with poorer marks are allocated places in less popular program not of their choosing (which includes social work). Students accept because any degree is better than no degree but it may well have a negative effect on their motivation towards social work, and indeed explain why only a minority enter and stay in the profession, as we saw earlier in this article.

The findings of the present study suggest that Chinese social work students' humanitarian ${ }_{\wedge}$ values are not a homogenous construct. In the context of different aspects of welfare reform experience may have a variable impact on students' value orientation. There is significant agreement between them about what they do and do not support. But the ideology of universalism is supported in some contexts, but not in others; universal welfare guaranteed in law, but individual responsibility in the provision of housing. Perhaps having had the experience of socialized housing provision, or learned about it from their parents, they are making a positive choice against something which is seen to have been, if not a failure, at least woefully inadequate.

Similar considerations can be seen at work in the association between the demographic factors of gender, and urban or rural background and whether welfare values were universal or context specific. In general, women showed higher levels of agreement with humanitarian ${ }_{\Lambda}$ values, possibly because women tend to be more altruistic than men and have a greater capacity to empathize with people in need (Vázquez, 2010). Gender and rural-urban differences concerning attitudes towards housing benefits could be explained by the self-interest hypothesis that posits that people tend to hold positive attitudes towards those benefits that they themselves have the potential to receive (Blekesaune \& Quadagno, 2003). Traditional gender roles mean that the burden of buying a home falls on the husbands' shoulders, which may explain why males are more in favor of universal housing benefits than females (Chan \& Leong, 1994). For urban students, housing and health care issues have a direct impact on their lives; while poverty will have been a grim reality in rural students' daily lives.

Humanitarian values were not officially recognized by the Chinese government and therefore not included in the guidelines drawn up for the social work profession. Contextual forces in social work teaching and learning also do not favor humanitarian ${ }_{\wedge}$ values. Thus it is hardly surprising to find that a longer exposure to their social work teachers and practice supervisors did not encourage the respondents' attitudes towards humanitarian ${ }_{\Lambda}$ values to become more positive as their studies progressed. No significant differences were found on five items comparing junior and senior level students. On at least three scale items the values of the senior students became less positive: willingness to accept poverty as inevitable, need for poverty alleviation and individual equality. This was in line with a previous study of general social science students (Cheung \& Kwok, 1998). As students approach 
graduation, the realities of job-seeking and career development become more apparent, as do the prospect of paying taxes, and carving out a successful personal future in the face of keen competition. The self-interest hypothesis, again, can be applied to explain the observed decreasing commitment to humanitarianism among senior students.

This drift away from humanitarian values may also be the result of the teachers and practitioners with whom they come into contact and who, presumably, act as professional role models. Social work is such a new profession in China that, as we have said, many of those teaching and practicing it have no formal professional training and cannot be assumed to have embraced a humanitarian ethos. Furthermore, the authoritarian teaching and learning style which characterizes teaching in China (Chan \& Chan, 2005) may inculcate a different set of values based on inequality, hierarchy and authority. Under such circumstances it is understandable that students learn to be less rather than more humanitarian through the cumulative effect of curriculum, practice placement and extra curricula activities (Lou et al., 2006).

\section{Limitations}

The present study has several limitations in design, sampling and measurement that may affect the validity of the findings. This study had to be designed around the realities of university placement and study and so an experimental design was not possible. The lack of a control group (for example, students studying other social science or science subjects) restricted further testing on value building. However, previous studies that included such comparison groups showed similar results - that university study produced few measurable enlightening effects (Cheung \& Kwok, 1998; Cheung, Chan, \& Lee, 1999). In addition, the study's cross-sectional design made it difficult to control age, cohort and period effects, caused by the changing social environment. The sample, even though including universities in two cities with different prestige levels and program nature, was ultimately a convenience sample. Generalization of the study findings to larger populations needs to be cautious. The measure adopted in the present study had been demonstrated to be a reliable measure among Chinese students, with satisfactory alpha scores for reliability. However, the measure lacked a strong theoretical framework (Tam, 2003).

\section{Implications for social work}

Four implications for social work education emerge from the findings of this study. First, students did not show a strong commitment to humanitarian welfare values in general. This is a worrying indicator of students' future motivation and commitment. Social work educators in China need to address this issue consistently and appropriately throughout the entire length of the social work program. First, however, they have to accept and personify those values themselves which potentially presents a fundamental difficulty. 
Second, the items that did not show any statistically significant differences between junior and senior students nonetheless had a negative direction; decreasing humanitarian ${ }_{\Lambda}$ values in the senior group. This should be an alarm signal for social work educators in China. Why, after studying social work knowledge and skills for three or four years, are students less inclined towards humanitarian values? Does the curriculum infuse humanitarian welfare values into each of the course objectives and content? Are there any other curriculum or extra-curricular activities that could be organized at a departmental or joint-university level to enhance humanitarian values?

Third, is this 'unenlightening' effect due to the traditional authoritarian teaching and learning strategies used by university teachers (Chan \& Chan, 2005)? Can it be explained by exposure to teachers and practitioners who are not professionally trained and who may themselves not embrace humanitarian values?

Fourth, our results tend to suggest that individual values are affected by individual's self-interest. Thus what seems a value worth espousing to students from rural areas, for example, the alleviation of poverty may not seem such a good idea to students from urban areas whose taxes may eventually have to pay for it. The respondents in our research had, on the whole, failed to internalize the humani$\operatorname{tarian}_{\Lambda}$ values that are considered a defining aspect of professional practice by international social work educators. How important is this? What are the implications for other cultures developing social work in Africa, South America and Asia?

The results of the present study suggest that social work professional value building is influenced by culture, tradition and context (e.g. the political economy in relation to welfare reform). Social work educators in China will need to give serious consideration to the issue of which values should underpin social work education and practice in their country and how these can be inculcated in students in a societal context which is both complex and changeable. The unspoken question, and the most difficult one, is whether the values that are accepted by the international social work organizations based on human rights, justice and equality will be thought desirable or even relevant in China. As the profession develops, the values espoused may be ones thought to be more coherent with Chinese culture and China's stage of economic and social development but they may not be the same as those espoused by the international community of social work. Whatever the outcome, there needs to be a debate.

\section{Conclusion}

The findings of the present study suggest that humanitarian ${ }_{\Lambda}$ values are not deeply embedded in social work students studying in Beijing and Shanghai. Female students tend to be more accepting of humanitarian ${ }_{\Lambda}$ values as compared with male students; a tendency to self-interest was observed that could explain differences in values between students from urban and rural areas. Social work undergraduate education seemed unable to strengthen humanitarian ${ }_{\Lambda}$ values among students; on the contrary, self-interest seems to have driven senior students to become less 
humanitarian compared with their junior peers. Social work knowledge and skills rather than values may be more immediately relevant to Chinese society. However, independent professional practitioners need a solid foundation of professional values to inform practice and standardize the social work role. There needs to be an ongoing debate in China among social work educators and practitioners about whether the current values espoused by social work that are based on Western philosophies and ethics are relevant in the Chinese context. How should values considered relevant be infused consistently into social work curricula in Chinese universities?

\section{Acknowledgements}

This project was supported by a China Research Grant, Department of Social Work and Social Administration, the University of Hong Kong. We would like to thank Dr K.W. Boey who initiated the project; Prof. D.H. Gu and Mrs W. Sha who coordinated the field work; and staff from the seven universities who helped to recruit participants.

\section{References}

Banks, S. (2001). Ethics and values in social work (2nd edn.). Houndmills: Palgrave.

Banks, S. (2004). Ethics, accountability and the social professions. Houndmills: Palgrave.

Blekesaune, M., \& Quadagno, J. (2003). Public attitudes toward welfare state policies: A comparative analysis of 24 nations. European Sociological Review, 19(5), 415-427.

Bond, M. H. (1988). Finding universal dimensions of individual variation in multicultural studies of values: The Rokeach and Chinese Value Surveys. Journal of Personality and Social Psychology, 55(6), 1009-1015.

Bronfenbrenner, U., \& Morris, P. (1998). The ecology of human developmental processes. In W. Damon \& R. M. Lerner (Eds.), The handbook of child psychology: Theoretical models of human development (Vol. 1, pp. 993-1028). New York: Wiley.

Chan, C. L. W., \& Chow, N. W. S. (1992). More welfare after economic reform? Welfare development in the People's Republic of China. Hong Kong: Department of Social Work and Social Administration, The University of Hong Kong.

Chan, K. L., \& Chan, C. L. W. (2005). Chinese culture, social work education and research. International Social Work, 48(4), 381-389.

Chan, S., \& Leong, C. (1994). Chinese families in transition: Cultural conflicts and adjustment problems. Journal of Social Distress and the Homeless, 3(3), 263-281.

Chen, H. L., Wong, Y. C., Ran, M. S., \& Gilson, C. (2009). Stress among Shanghai University students: The need for social work support. Journal of Social Work, 9(3), 323-344.

Chen, J., Hou, W., \& Jin, S. (2008). A review of the Chinese Gini Coefficient from 1978 to 2005. Social Science Research Netowrk, working paper series.

Cheung, C. K., \& Kwok, S. T. (1998). Social studies and ideological beliefs in Mainland China and Hong Kong. Social Psychology of Education, 2(2), 217-236.

Cheung, C. K., \& Kwok, S. T. (1999). Redefining the value structure of college students in Hong Kong and the Mainland of China. Social Research and Personality, 27(2), 195-204.

Cheung, C. K., \& Tang, K. L. (2010). Socialization factors conducive to social work students' gain in competence: Experience in the Hong Kong SAR, China. Journal of Social Work, 10(1), 42-58. 
Cheung, C. K., Chan, C. M., \& Lee, J. J. (1999). Beliefs about elderly people among social workers and the general public in Hong Kong. Journal of Cross-Cultural Gerontology, 14(2), 131-152.

China Association of Social Work Education. (2009). Name list of Members (institute that offer social work program). Retrieved September 2009 from: http://www.chinaswedu. com/news/JYXH_JBQK/2008/3-20/08320142950B8989KGGG6KC9DG6663J.shtml (in Chinese).

Chow, N. W. S. (1987). Western and Chinese ideas of social welfare. International Social Work, 30(1), 31-41.

Croll, E. (1999). Social welfare reform: Trends and tensions. The China Quarterly, 159(suppl.), 684-699.

Gong, S., \& Li, B. Q. (2003). Social inequalities and wage, housing and pension reform in urban China. Asia Programme Working Paper No. 3, The Royal Institute of International Affairs, London.

Gray, M. (2008). Some considerations on the debate on social work in China: Who speaks for whom? International Journal of Social Welfare, 17(4), 400-406.

Gustafsson, B., Li, S. \& Sicular, T. (Eds.) (2008). Inequality and public policy in China. Cambridge: Cambridge University Press.

He, G. L. \& Wang, S. B. (Eds.) (2000). Chinese society: Exploring the essence of social work. River Edge, NJ: Global Publishing Co. Inc. (in Chinese).

Huang, Y. M. (2006). Exploiting and applying the resources of traditional culture and localizing the values of social work. Journal of Zhangzhou Teachers College, 20(3), 40-44 (in Chinese).

Hutchings, A., \& Taylor, I. (2007). Defining the profession? Exploring an international definition of social work in the China context. International Journal of Social Welfare, 16(4), 382-390.

International Association of Schools of Social Work (IASSW) and International Federation of Social Workers (IFSW). (2009). Ethics in social work, statement of principles. Retrieved September 2009: http:/www.iassw-aiets.org/index.php? option $=$ com_content $\&$ task $=$ blogcategory $\&$ id $=27 \&$ Itemid $=50$.

Jia, C. (2007). Correcting misconceptions about the development of social work in China: A response to Hutchings and Taylor. International Journal of Social Welfare, 17(1), 98-101.

Jia, W. D., \& Zheng, H. Y. (2006). Overview of the contemporary university students' choice of occupation. Journal of Zhangjiakuo Vocational College of Technology, 19, 13-15 (in Chinese).

Jiang, H. Y. (2008). Studies of welfare ideology: Developing perspectives on China. Journal of East China University of Science and Technology (Social Science Edition), 28(1), 19-24 (in Chinese).

Kendall, K. A. (2000). Social work education: Its origins in Europe. Alexandria, VA: Council on Social Work Education.

Lee, J., \& Zhu, Y. (2006). Urban governance, neoliberalism and housing reform in China. The Pacific Review, 19(1), 39-61.

Liu, R. (2006). Professionals with pure motives. Shanghai Star, 17-24 January. Retrieved September 2009 from: http://app1.chinadaily.com.cn/star/2006/0117/ci2-1.htm.

Liu, X. B., Li, Y. J., \& Feng, F. (2008). Thirty years of legal theory in China's reform and opening up: 1978-2008. Law and Social Development, 14(5), 3-36. 
Lottes, I. L., \& Kuriloff, P. J. (1994). The impact of college experience on political and social attitudes. Sex Role, 31(1/2), 31-54.

Lou, V. W. Q., Gu, D. H., Kuan, Y. Y., \& Leung, J. C. B. (2006). Final report on the profile of social work programs and training needs of higher education in the Chinese communities - Mainland China, Hong Kong and Taiwan. Report submitted to the International Association of Schools of Social Work.

Lu, L. (2008). The individual-oriented and social-oriented Chinese bicultural self: Testing the theory. The Journal of Social Psychology, 148(3), 347-373.

Lu, M., \& Feng, M. (2008). Reforming the welfare system in the People's Republic of China. Asian Development Review, 25(1/2), 58-80.

Lubman, S. B. (1999). Bird in a cage: Legal reform in China after Mao. Palo Alto, CA: Stanford University Press.

Ministry of Civil Affairs of the People's Republic of China. (2009). National Occupational Standard for Social Workers. Retrieved September 2009 from: http://sw.mca.gov.cn/ article/zcwj/200710/20071000002534.shtml (in Chinese).

Moran, J. R. (1989). Social work education and students' humanistic attitudes. Journal of Social Work Education, 25(1), 13-19.

Pascarella, E. T., \& Terenzini, P. T. (1991). How college affects students: Findings and insights from twenty years of research. San Francisco, CA: Jossey-Bass.

Pullen, A. (2006). Ethics and values in social work. Houndmills: Palgrave.

Rompf, E. L., \& Royse, D. (1994). Choice of social work as a career: Possible influences. Journal of Social Work Education, 30(2), 163-171.

Tam, T. S. K. (2001). Humanitarian attitudes and support of government responsibility for social welfare: A study of perceptions of social work graduates in the People's Republic of China. Asia Pacific Journal of Social Work, 11(2), 34-52.

Tam, T. S. K. (2003). Humanitarian attitudes and support of government responsibility for social welfare: A study of perceptions of social work graduates in Hong Kong and the People's Republic of China. International Social Work, 46(4), 449-467.

United Nations Human Development Report Office. (2005). Human development report 2005: Poverty, pro-poor growth and simulated inequality reduction. Geneva: The Author.

Vázquez, J. (2010). Attitudes toward nongovernmental organizations in Central America. Nonprofit and Voluntary Sector Quarterly, doi:10.1177/0899764009359944.

Wong, X. R. (2002). A survey on career choices of social work graduates in Shanghai. China Social Welfare, 2(8), 37-40 (in Chinese).

Xie, Q. W. (2006). A survey on career choices of social work graduates. China University Students Career Guide, 7(23), 36-38 (in Chinese).

Yan, W. (2006). Value changes in an era of social transformations: College-educated Chinese youth. Educational Studies, 32(2), 233-240.

Yang, K. (2004). A theoretical and empirical analysis of the Chinese self from the perspective of social and individual orientation. Indigenous Psychological Research in Chinese Societies, 22(2004/12), 11-80.

Yu, C., \& Li, L. W. (2006). Investigations upon the employment status of the first graduates majoring in social work in Jiangxi Province. Social Work, 8(11), 20-22 (in Chinese). 